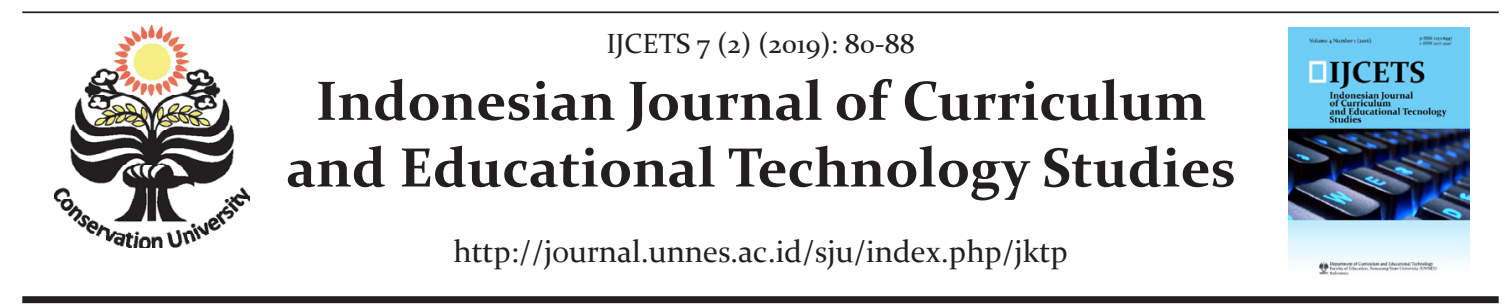

\title{
Understanding Climate Change Topics Critically Through Android-based Module for Student
}

\author{
Titis Nindiasari Anggraeni, ${ }^{\mathbb{\otimes}}$ Tien Aminatun $^{2}$ \\ ${ }^{12}$ Department of Biology Education, Universitas Negeri Yogyakarta, special region of Yogyakarta, \\ Indonesia
}

DOI: https://doi.org/10.15294/ijcets.v7i2.32146

\section{Article History \\ Received : July 2019 \\ Accepted : August 2019 \\ Published : November 2019}

\section{Keywords}

Android-based module; climate change; critical thinking; SSCS

\begin{abstract}
Abstrak
Perubahan iklim adalah masalah dunia yang mendesak yang harus dihadapi secara kritis oleh siswa. Artikel ini menggambarkan satu upaya meningkatkan keterampilan berpikir kritis siswa terhadap topik-topik perubahan iklim dalam mata pelajaran di sekolah melalui pengembangan modul pembelajaran berbasis Android. Dengan menggunakan pendekatan Design \& Development Research (DDR) penelitian ini menggunakan model pembelajaran Search, Solve, Create, dan Share (SSCS) dalam pengembangan modulnya. Pada akhir proses, modul siap digunakan karena perbandingan antara kelas eksperimen dan kelas kontrol menunjukkan bahwa ada peningkatan keterampilan berpikir kritis siswa ketika mereka menggunakan modul tersebut. Dengan demikian, Android dan produk teknologi lainnya harus diakui memiliki potensi besar untuk mendorong kesadaran dan daya kritis siswa terhadap masalah perubahan iklim.
\end{abstract}

\begin{abstract}
Climate change is urgent world issue that should be face critically by student. This article tries to illustrate one effort to improve student critical thinking skill toward climate change topics through developing Android-based learning module. By employing design and development research (DDR) approach this research using Search, Solve, Create, and Share (SSCS) learning model on producing the module. In the end of the process the module is ready for use because the comparison between experimental class and control class indicates that there is an increasing of student critical thinking skills when they use the module. Therefore, Android and others technological product should be recognize as having huge potential to encourage student awareness and critical thinking toward climate change issues.
\end{abstract}




\section{INTRODUCTION}

The learning process is essentially a communication process realized through the delivery of information to students. The information conveyed can be in the form of knowledge, expertise, skills, ideas, experience, and so on which packed as teaching materials (Ditjen PMPTK, 2008, p. 6). Educators must have the ability to develop teaching materials for the realization of student competency development.

Teaching materials must be able to facilitate students to involve in active learning activities. Both teachers and students may take advantage of the teaching materials. Teachers' role has been changed into a facilitator striving for an effective and interactive learning process. On the other hand, useful teaching materials help potential learners to become independent as they can learn following their respective speeds at any time and anywhere (Prastowo, 2014, pp. 139-140).

One of the forms of teaching materials focusing on the independent learning process is a module. With the module, students will easily learn at any time and anywhere independently (DG PMPTK, 2008: 3). Learning using modules has several advantages including (1) increasing the effectiveness of learning without having face-to-face meetings regularly; (2) determining and setting study time in line with the needs and development of student learning; (3) expressly knowing students' competency achievement gradually through the criteria set out in the module; and (4) knowing the weaknesses or competencies that have not been achieved based on the criteria set out in the module so that teachers can decide and help students to improve their learning through remediation (Ditjen PMPTK, 2008, p. 7).

Frankly speaking, the use of modules in the learning process facilitates students to develop knowledge and master competencies that have been set independently. In this study, researchers developed an Android-based module. Cabanban \& Marcos (2013, p. 99) stated that Android is an open-source mobile device operating system that is supported by Google Corporation. Tong (2016, p. 1) added that the Android system is the first complete, open and free cellular development platform as well as the main smartphone operating system that is used either domestically and internationally.

Calimag, Miguel, Conde, \& Aquino (2014, p. 124) added that Android was built to enable developers to create interesting mobile applications. It is an open operating system that can be extended freely to combine various emerging technologies; also a platform that will continue to develop along with the growth of developer communities who work together to generate innovative applications. Thus, the development of an Android mobile-based module is expected to increase students' learning motivation through the convenience offered, interactive and interesting presentation, as well as accessibility. This is the opposite of printed modules that tend to be used passively as they are relatively not interactive. Besides, they are generally large and heavy that will certainly be difficult to carry anywhere and anytime.

The concept development is inspired by the recent condition of DIY, which is facing great climate change and environmental problems than years before. The level of pollution is getting higher, especially solid waste in the form of garbage, which should be a concern for the people of special region of Yogyakarta (DIY). Rumour has it that the closure of the Piyungan Integrated Waste Disposal Site (Tempat Pembuangan Sampah Terpadu/TPST) is due to the fact that TPST has been overloaded and is no longer able to accommodate garbage. This has an impact on the accumulation of garbage in landfills (Tempat Pembuangan Akhir/TPA) in several regions in DIY ("Dibalik TPST Piyungan yang 'Ditutup," 2019).

This research was conducted at the AlAzhar Islamic High School, Yogyakarta, which is located close to the landfill, so that it has both direct and indirect impacts. Thus, the problem of environmental change becomes a relevant problem for further study mainly by the students to find solutions to it.

Furthermore, survey results on the availability of internet networks in high schools of Sleman, Yogyakarta showed that 91\% of schools already had internet networks. The utilization of the internet for learning activities has reached $61 \%$ and the flexibility given by the school to students to use smartphones during lesson hours was $82 \%$. However, this discretion has not yet been utilized for learning biology, as evidenced by the results of a survey which showed that $100 \%$ of the schools have not been used smartphones as learning media (e-modules) in biology learning (Aminatun et al., 2016, p. 18). Therefore, it is necessary to develop e-modules packed in an application that can be used on Android-based 
T.N. Anggraeni et al/Indonesian Journal of Curriculum and Educational Technology Studies 7(2) (2019): $80-88$

smartphones.

The researches of this study referred to Pizzini (1991, p. 3) who revealed that the search, solve, create, and share (SSCS) is a potential learning model that involves learners in exploring new situations, considering interesting questions, and solving real problems. The SSCS learning model has made students actively participate in applying content, concept, and higherorder thinking skills. Problem-solving surely will be appropriate to learn about climate change as it is a real issue to overcome.

Chin (1997, p. 9) revealed that SSCS is a problem-solving model enabling students to identify problems so that they can experience meaningful learnings through concrete issues. In line with this, Pizzini (1991, p. 3) argued that the SSCS model is designed to enlarge and apply science concepts as well as critical thinking skills which are very beneficial for everyday life. Moreover, Ricci (2013, p. 65) argued that Critical thinking and a growth mindset culture go hand in hand. $\operatorname{BSNP}(2010$, p. 44) elucidated that critical thinking skills are included as one of the competencies to be mastered by the 21st century human resources. For that reason, the learning process should empower and improve critical thinking skills (Haryono, Subkhan, \& Widhanarto, 2017).

Bellanca, Fogarty, and Pete (2012, p. 13) said that critical thinking is a combination of problem-solving and decision making. This critical thinking ability consists of three skills namely analyzing, evaluating, and solving problems. Daniel Willingham (2008) a Professor of Theory of Psychology at the University of Virginia as quoted by Ricci (2013, p. 55) stated similar things that three types of thinking are included in critical thinking: reasoning, decision making, and solving problems. Thus, critical thinking skills can be developed through problem-solving activities by identifying and analyzing a problem (search), solving a problem (solve), making a product of the problem-solving results and concluding (create), communicating the findings, and receiving feedback (share).

Basically, the critical approach has been broadly suggested as the approach to the study of climate change as a part of environmental problems (Peterson, 2019). That is because a critical approach will invite students to reflect on the environment in which they live, what problems arise, and direct students to try to provide solutions to the problems. The problem of cli- mate change does not only require students to merely understand, but encourage students to be involved in efforts to overcome them.

Based on some of these considerations, the research described in this article illustrates how a greatly crucial topic, namely environmental damage and climate change, is directed to be critically studied using the Android-based learning module with search, solve, create, and share (SSCS) model. This research thus contributes to providing alternative learning media for climate change materials through the development of digital technology-based learning media which is a central part of the field of educational technology studies (see Januszewski \& Molenda, 2008).

\section{METHOD}

The Design and Development Research is the model used in this research. Richey \& Klein (2007, p. 1) revealed that Design and Development Research is a systematic study of design, development and evaluation processes aimed at establishing an empirical basis for the production of instructional and non-instructional products and devices, new or improved models. The product developed in this study is a mobile Android based biology module that was prepared according to the syntax of the SSCS learning model.

The development procedure used as a reference in this research was the Design and Development Research (DDR) model. The model has 4 stages, namely validity, causal inferences, generalization and interpretation, and anticipating problems. However, the development carried out in this study was limited to the stage of validity comprising 4 steps of development, namely the model development, internal validation model, external validation model, and model implementation (Richey \& Klein, 2007).

At the model development, the initial step taken was to establish a framework of thinking that is based on knowledge and literature studies relevant to the developed product. The next step was to create a conceptual framework which is the flow of thought in designing Android-based modules.

At the validation model (internal) stage, the module developed was validated internally based on face validity assessments, namely substance/material experts, construction experts, and peers. Moreover, the validated aspects inclu- 
ded the substance and construction aspect.

In the validation model (external) stage, the developed Android-based module was assessed by biology teachers and tested limited to 10 students of XI Al-Azhar High School, Yogyakarta. At the model implementation stage, the developed Android-based module was implemented in formal learning in the classroom through field trials. The trial design was nonrandomized subject and pretest-posttest control group design because the researchers involved the existing classes which are believed to be randomly divided during class divisions (Arry, Jacobs \& Sorensen, 2010, p. 316).

Table 1 The research design

\begin{tabular}{lrcc}
\hline Class & Pretest & Treatment & Posttest \\
\hline Experimental & $\mathrm{O}_{1}$ & $\mathrm{X}_{1}$ & $\mathrm{O}_{2}$ \\
Control & $\mathrm{O}_{3}$ & $\mathrm{X}_{2}$ & $\mathrm{O}_{4}$ \\
\hline
\end{tabular}

Information:

O1: Pretest of the students' critical thinking skills prior to the application of the Android-based biology module with SSCS.

Xı: Treatment by applying the Android-based biology module with SSCS.

O2: Posttest of the students' critical thinking skills after the use of the Android-based biology module with SSCS.

$\mathrm{O}_{3}$ : Pretest of the students' critical thinking skills prior to the implementation of the SSCS model.

X2: Treatment by applying the SSCS learning model without the Android-based module.

$\mathbf{O}_{4}$ : Posttest of the students' critical thinking skills after the use of the SSCS model.

The subjects of the field trials were $\mathrm{X}$ graders of SMA Al-Azhar Yogyakarta split into one control class and one experimental class. The field trials were conducted to determine the effectiveness of the Android-based module in improving the students' critical thinking skills in the experimental class. The sample was taken from 2 classes out of 3 existing classes using the conventional technique. The technique was adopted due to the availability of samples so that they could be chosen easily as a basis for inferential procedures.

This study employed the nature of the population so that the samples taken could be considered random. From this method, the population used was hypothetical and the research results could be sampled in experimental research (Daniel, 1989, p. 4). The determination of the experimental and the control class was carried out through drawing. The data collection techniques included test and non-test. The test was an essay describing critical thinking skills while the non-test was in the form of questionnaires with the Likert's rating scale model.

The data obtained were in the form of qualitative and quantitative data. The qualitative data included input and responses from material experts, construction experts, peers, biology teachers, and students to improve the product being developed. The quantitative data consisted of module assessment scores and pretestposttest scores to measure the effectiveness of the product in improving critical thinking skills. The data of the pretest-posttest value were analyzed using anacova test to determine the effect of the Android-based module with the SSCS model to improve critical thinking skills.

\section{RESULT AND DISCUSSION}

The results and discussion consist of four parts, namely (1) the results of product development, (2) product revisions, (3) final product studies, and (4) research limitations.

\section{A. The Product Development Result}

The product development referred to the Design and Development Research (DDR) model established by Richey and Klein yet limited on the validity stage comprising 4 steps of development, namely the model development, internal validation model, external validation model, and model implementation.

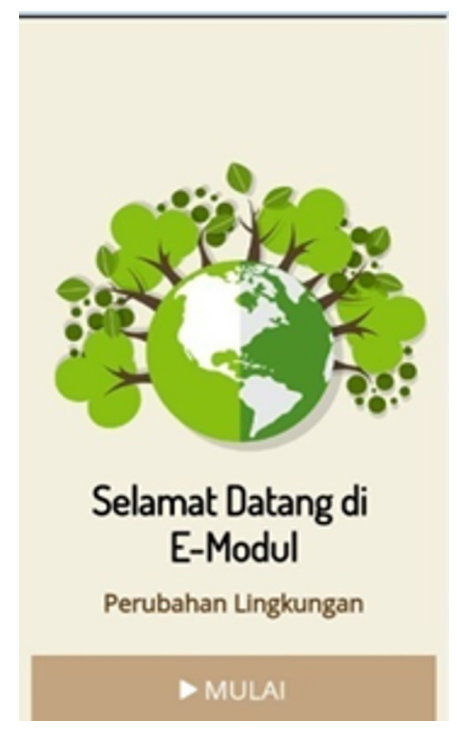

\section{Figure 1 Homepage}

In the model development phase, the Android-based module was developed through an analysis of system requirements described in a framework of thought. A need analysis on sys- 
T.N. Anggraeni et al/Indonesian Journal of Curriculum and Educational Technology Studies 7(2) (2019): $80-88$

tem requirement was based on a theoretical study that reviews the advantages of Android-based modules compared to print modules. Furthermore, the module was developed with a reference storyboard that has been compiled.

Specifically, the system requirements for developing the Android-based module include module components, software, and hardware. The compiled module structure includes the module title, preface, competency and indicators, learning objectives, learning activities according to SSCS syntax, material description, formative questions/tests, glossary, and etc. The internal validation is the stage of module evaluation from material experts, construction experts (learning and media), and peers (peer reviewers).

Table 2 Substance experts' validation results

\begin{tabular}{clc}
\hline No & Assessment Aspect & Score \\
\hline 1 & $\begin{array}{l}\text { The suitability of the materials } \\
\text { with basic competencies }\end{array}$ & 4 \\
2 & $\begin{array}{l}\text { The truth of the concept } \\
3\end{array}$ & 3 \\
& $\begin{array}{l}\text { The suitability of the examples } \\
\text { with the materials }\end{array}$ & 4 \\
4 & $\begin{array}{l}\text { Fact accuracy } \\
5\end{array}$ & $\begin{array}{l}\text { Coherence and chronologic of the } \\
\text { thinking framework }\end{array}$ \\
6 & $\begin{array}{l}\text { Contextuality of the presented } \\
\text { materials }\end{array}$ & 3 \\
\hline Total score & 21 \\
\hline Criteria & Excellent \\
\hline
\end{tabular}

Several inputs and suggestions given were (1) some concepts have to be emphasized, (2) it needs to include materials about environmental quality standards, (3) examples/illustrations must be added, (4) facts (including data or scientific information) supporting the concepts should be included, (5) examples of context, especially for cultural aspects must be inserted, and (6) ensuring that the SSCS approach is representative.

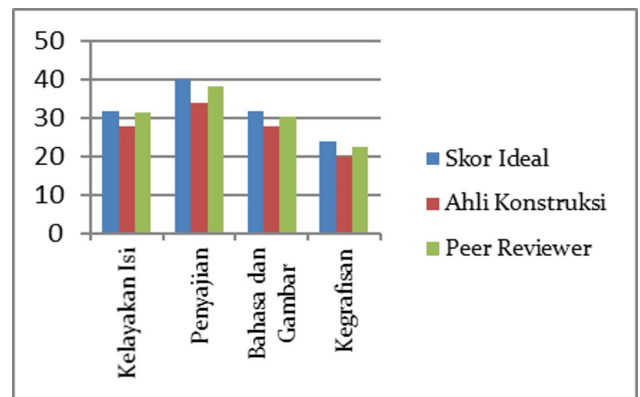

Figure 2 Expert and peer reviewer assessment results
The external validation is the stage of module assessment from the biology teachers and students in limited trials.

Table 3 Biology teacher assessment results

\begin{tabular}{lllll}
\hline Assessor & $\begin{array}{l}\text { Content } \\
\text { feasibi- } \\
\text { lity }\end{array}$ & $\begin{array}{l}\text { Presen- } \\
\text { tation } \\
\text { quality }\end{array}$ & $\begin{array}{l}\text { Langu- } \\
\text { age and } \\
\text { figure } \\
\text { quality }\end{array}$ & $\begin{array}{l}\text { Graphic } \\
\text { quality }\end{array}$ \\
\hline Teacher 1 & 30 & 40 & 30 & 24 \\
Teacher 2 & 31 & 36 & 29 & 21 \\
Average & 30.5 & 38 & 29.5 & 22.5 \\
\hline Criteria & $\begin{array}{l}\text { Excel- } \\
\text { lent }\end{array}$ & $\begin{array}{l}\text { Excel- } \\
\text { lent }\end{array}$ & $\begin{array}{l}\text { Excel- } \\
\text { lent }\end{array}$ & $\begin{array}{l}\text { Excel- } \\
\text { lent }\end{array}$ \\
\hline
\end{tabular}

Some of the suggestions given by the teachers including (1) either the materials and pictures are appropriate and each sub-theme should be spaced so that it is not too full of writing, (2) the application can be developed into the $\mathrm{iOS} / \mathrm{iPhone}$ operating system so that it can be used by all circles.

Table 4 The module assessment results on the limited scale trials

\begin{tabular}{lllll}
\hline No & $\begin{array}{l}\text { Assessment } \\
\text { Aspect }\end{array}$ & $\begin{array}{l}\text { Number } \\
\text { of Items }\end{array}$ & $\begin{array}{l}\text { Average } \\
\text { of Total } \\
\text { Score }\end{array}$ & Criteria \\
\hline 1 & $\begin{array}{l}\text { Content } \\
\text { feasibility }\end{array}$ & 4 & 12 & Good \\
2 & $\begin{array}{l}\text { Presentation } \\
\text { quality }\end{array}$ & 6 & 20 & Excellent \\
3 & $\begin{array}{l}\text { Language } \\
\text { and figure } \\
\text { quality }\end{array}$ & 12 & 38 & Good \\
4 & $\begin{array}{l}\text { Graphic } \\
\text { quality }\end{array}$ & 6 & 20 & Excellent \\
5 & Ease of use & 3 & 9.1 & Good \\
\hline
\end{tabular}

The model implementation is the stage of applying the Android-based module with the SSCS model. The field trial phase aimed to find out the quality and effectiveness of the module which was conducted in the 4th week of April to the 2nd week of May 2019 at SMA Al-Azhar, Yogyakarta. The class used as the experimental was X IPA 2 consisting of 24 students and X IPA 3 with 21 students as the control class. The field trials resulted in the experimental class student responses to the module and critical thinking scores from the pre- and post-test both in the experimental and control class. Table 5 below illustrate the result. 
T.N. Anggraeni et al/Indonesian Journal of Curriculum and Educational Technology Studies 7(2) (2019): $80-88$

Table 5 The module assessment results on the field scale trials

\begin{tabular}{llll}
\hline No & Assessment Aspect & $\begin{array}{l}\text { Average of } \\
\text { Score }\end{array}$ & Criteria \\
\hline 1 & Content feasibility & 13 & Excellent \\
2 & Presentation quality & 19 & Good \\
3 & Language and figure & 37 & Good \\
& quality & & \\
4 & Graphic quality & 19 & Good \\
5 & Ease of use & 9,3 & Good \\
\hline
\end{tabular}

The students suggested that (1) the module should be available on the Appstore (iOS) so that Apple/iPhone users could access it, (2) zooming and scrolling interference on pages with pictures should be fixed, (3) there should be the iPhone version, and (4) the application makes learning easier.

Thi research examined the influence of the developed Android-based module on the students' critical thinking skills in the control and experimental class. The data were gathered using an essay test whose descriptive statistical analysis results are presented in Table 6.

Table 6 Descriptive statistical analysis results

\begin{tabular}{lcccc}
\hline & \multicolumn{2}{c}{ Experimental class } & \multicolumn{2}{c}{ Control class } \\
\cline { 2 - 5 } & Pretest & Posttest & Pretest & Posttest \\
\hline Average & 65.08 & 92.38 & 68.43 & 87.52 \\
Ideal Score & 100 & 100 & 100 & 100 \\
Max Score & 89 & 100 & 92 & 100 \\
Min Score & 39 & 81 & 42 & 58 \\
\hline Posttest- & \multicolumn{2}{c}{27.3} & \multicolumn{2}{c}{19.09} \\
Pretest & & & & \\
average & & & & \\
difference & & & & \\
\hline
\end{tabular}

Based on Table 6, the average value of pretest on the critical thinking skills of the experimental class students was 65.08, and the posttest average value was 92.38. Further, the average pretest value of the students' critical thinking skills in the control class was 68.43 , and 87.52 for the average posttest score. The mean pretest value of the experimental class was lower than the control class yet in the posttest, the experimental class' average was higher than the control class. It can be seen from the difference in the average posttest-pretest value of the experimental class that was higher than the control class. This shows that there is a significant influence of the Android-based modules with SSCS to improve the students' critical thinking skills. For more details, inferential statistical analysis was performed.

The number of samples in this study was less than 50; therefore, the data normality test was performed with the Shapiro-Wilk Test with a significance level of 0.05 (Yap \& Sim, 2011: 2143). The results of the normality test can be seen in Table 7 .

Table 7 The normality test results

\begin{tabular}{llllll}
\hline Class & Data & Df & Sig. & $\begin{array}{l}\text { Sig. } \\
\text { Level }\end{array}$ & $\begin{array}{l}\text { Infor- } \\
\text { mation }\end{array}$ \\
\hline $\begin{array}{l}\text { Experi- } \\
\text { mental }\end{array}$ & Pretest & 24 & 0.364 & $>0.05$ & Normal \\
& Posttest & & 0.028 & $<0.05$ & $\begin{array}{l}\text { Not } \\
\text { Normal }\end{array}$ \\
\hline $\begin{array}{l}\text { Con- } \\
\text { trol }\end{array}$ & Pretest & 21 & 0.504 & $>0.05$ & Normal \\
& & & & & \\
& Posttest & & 0.002 & $<0.05$ & $\begin{array}{l}\text { Not } \\
\text { Normal }\end{array}$ \\
\hline
\end{tabular}

Based on the data normality test results, the pretest scores in the experimental and control class were normally distributed, while the posttest results in the experimental and control class were not normally distributed (sig <0.05). This was drawn from the significance value of the experimental and control class pretest data which was greater than 0.05 , while the posttest data of the experimental and control class was smaller than 0.05 .

The homogeneity test employed a Levene test with a significance level of 0.05 . The test results can be seen in Table 8 .

Table 8 Homogeneity variance test results

\begin{tabular}{lcccc}
\hline & $\begin{array}{l}\text { Levene } \\
\text { Statistic }\end{array}$ & $\mathrm{df1}$ & $\mathrm{df2}$ & Sig. \\
\hline Pretest & .127 & 1 & 43 & .724 \\
Posttest & 6.528 & 1 & 43 & .014 \\
\hline
\end{tabular}

Based on the data of the homogeneity test, it is known that the significance value of pretest group data was $0.725>0.05$, thus, the variance of pretest group data was homogeneous. Further, the significance value of the posttest group data was $0.014<0.05$ and classified as not homogeneous. The results of the regression test can be seen in Table 9. 
T.N. Anggraeni et al/Indonesian Journal of Curriculum and Educational Technology Studies 7(2) (2019): $80-88$

Table 9 The regression test results

Coefficients

\begin{tabular}{|c|r|r|r|r|r|}
\hline Model & \multicolumn{2}{|c|}{$\begin{array}{c}\text { Unstandardized } \\
\text { Coefficients }\end{array}$} & $\begin{array}{c}\text { Standard } \\
\text { ized } \\
\text { Coefficie } \\
\text { nts }\end{array}$ & $\mathrm{t}$ & Sig. \\
\cline { 2 - 4 } & $\mathrm{B}$ & \multicolumn{1}{|c|}{$\begin{array}{c}\text { Std. } \\
\text { Error }\end{array}$} & Beta & & \\
\hline (Constant) & 84.839 & 4.604 & & 18.428 & .000 \\
I Kelas & .116 & .069 & .336 & 1.674 & .108 \\
\hline
\end{tabular}

a. Dependent Variable: Posstest

Based on the regression test results, the significance value of $t$ o.ooo is known so that the data were linear. After that, the hypothesis test was conducted. The results of the normality test showed that the distribution of pretest data was normal and homogeneous, while the distribution of posttest data was neither normal or homogeneous. Besides, the results of the regression test indicated that the pretest-posttest data were linear. The anacova test, whose outtakes are observable in Table 10, was conducted to see the effectiveness of the Android-based module with SSCS to improve the students' critical thinking skills.

Table 10 The Anacova test results

\begin{tabular}{lccccc}
\hline Source & $\begin{array}{l}\text { Type III } \\
\text { Sum of } \\
\text { Squares }\end{array}$ & df & $\begin{array}{l}\text { Mean } \\
\text { Square }\end{array}$ & F & Sig. \\
\hline $\begin{array}{l}\text { Corrected } \\
\text { Model }\end{array}$ & $421.95 \mathrm{a}$ & 2 & 210.98 & 3.24 & .049 \\
$\begin{array}{l}\text { Intercept } \\
\text { Perlaku- }\end{array}$ & 2379.12 & 1 & 2379.12 & 36.59 & .000 \\
an & 294.31 & 1 & 294.34 & 4.52 & .039 \\
Error & 2730.48 & 42 & 65.01 & & \\
Total & 368553.00 & 45 & & & \\
\hline Corrected & 3152.44 & 44 & & & \\
Total & & & & & \\
\hline a. R Squared $=.134$ (Adjusted R Squared $=.093)$ &
\end{tabular}

Referring to the anacova test results, most of the students in the experimental class experienced an increase in critical thinking skills as indicated by the value of $\mathrm{F}=452 ; \mathrm{p}<0.05$. Thus, the established module is effective for improving their critical thinking skills.

The instrument used to measure students' critical thinking skills in the control class and the experimental class was an essay test consisting of 10 items. The question is a test item to identify learning achievement (criterion-referenced test). The validity of the item investigation can be seen from the item sensitivity index (Subali \& Suyata, 2012, pp. 119-120) and the sensitivity index values for the experimental and the control class are presented in Table 11.

Table 11 The average value of sensitivity index in the experimental and control class

\begin{tabular}{cc}
\hline \multicolumn{2}{c}{ Sensitivity Index (SI) } \\
\hline Experimental Class & Control Class \\
0.61 & 0.43 \\
\hline
\end{tabular}

Based on Table 11, it can be seen that the sensitivity index for the experimental class was $>0.50$. This shows that the learnings were done well. In the control class, the sensitivity index $<0.50$. This means that the learnings were done unwell.

\section{B. Product Revision}

The developed product has been revised three times. The first revision was carried out according to the material/substance expert, construction expert, and peers. The second revision was carried out according to the advice of the biology teachers and students in the limited trials. Moreover, the third revision was done after the field trials.

The first stage of product revision was based on advice given by the material and construction experts as well as colleagues, which includes (1) the addition of materials about environmental quality standards, (2) the addition of examples/illustrations/pictures describing the process of handling waste, (3) the exclusion of the initial narrative on the learning activities 1 and revising the learning activities 2 to create a more representative SSCS approach.

The second stage of the revision was carried out based on the suggestions given by biology teachers and students in the limited trial. These revisions include (1) the addition of videos relevant to the materials to strengthen and broaden the students' insights, (2) the improvement of "links" that do not match the intended web address, (3) the repair of the sentences or words that are considered less appropriate or ambiguous, (4) re-selection of some images displayed in learning activities 2.

The third stage of product revision was done referring to the suggestions and inputs from the students during the field trial. Generally, the learners suggested that the module be developed for the iOS/iPhone operating system 
so that iPhone users can access it. However, the researchers could not realize it since iOS has a higher level of difficulty than the Android operating system in terms of application building and the availability period on the AppStore which must be updated every year at a certain cost. Besides, learners using Android operating systems are greater in numbers than those using the iPhone.

\section{Final Product review}

The Android-based module with the SSCS model on environmental change topic was developed to improve the students' critical thinking skills. This product has passed the development stages that refer to Richey \& Klein's (2007) DDR model. These stages consist of the development stage (model development) to the stage of model implementation. The final product can be downloaded on Google Playstore using the keyword of 'e-module on environmental change' and can be operated either online or offline.

The established module is designed to facilitate students to be able to carry out independent learning activities according to their potential without relying entirely on the teacher. Besides, the development aims to improve the students' critical thinking skills. Klebba \& Hamilton and Smith as quoted by Kawamura \& $\mathrm{Wu}(2015$, p. 1) revealed that the use of innovative teaching methods by utilizing technology to provide the latest content to students to grow critical thinking skills is a common thing. Therefore, to find out the effectiveness of the module as an innovative effort to improve critical thinking skills, the field trials were conducted. Based on the field trial results, the Android-based module with the SSCS model is effective in improving the students' critical thinking skills seen from the results of anacova test with a value of $F$ $=4528 ; \mathrm{p}<0.05$. Thus, the experimental class can be said to be superior to the control class.

The strengths of the module include the flexibility of use without being bound by time and space as Android devices are small, lightweight, and easy to carry (Lubis \& Ikhsan, 2015, p. 199). This provides an opportunity for students to learn independently according to the potential possessed by each student, which is also in line with the characteristics of the 2013 curriculum that emphasizes student-centered learning. Also, the Android-based module is an open-source that allows developers to create diverse applications. Zheng, Cheng, \& Peng (2015, p. 287) stated that mobile learning has broader application prospects due to the availability of various applications in the Android operating system which is expected to increase students' learning motivation.

Behera (2013, p. 31) argued that mobile learning, in this case; an Android-based module, can do many things to enrich the learning experience. The SSCS model integrated with the module has a sequential and clear syntax that allows the students to play an active role in the learning process. Learners conduct group discussions, identify problems, and find solutions to the problems faced. By using the module, the students can find relevant information from various websites and social media available in the module. The problems faced by the students require them to think critically in finding various solutions and alternative solutions to the problems. Thus, the use of the Android-based module with the SSCS model is effective in increasing the students' critical thinking skills.

\section{CONCLUSION}

The data analysis results and discussion of the development conclude that the Androidbased module with the SSCS model on environmental change topic is feasible to be used as a learning source in terms of substance and construction by the substance experts, construction experts, teachers, and colleagues. Furthermore, the module has been declared effective in improving the critical thinking skills of high school students.

Nevertheless, some limitations are found. The module is limited, for now, to devices with the Android operating system like smartphones or tablets so that some students in the experimental class could not download the application. The development research in the field trial was also limited to 1 school, the Islamic High School Al-Azhar Yogyakarta so that a feasibility test on a broader scale is needed. The stages of development are also limited to the validity stage so that they can be developed to the next stage.

\section{REFERENCES}

Aminatun, T., Subali, B., Prihartina, I., Masing, F. A., Dwiyani, A., Nindiasari, T., ... Luthfi, M. (2016). Pengembangan e-Modul Berbasis Android Mobile Materi Ekosistem Lokal Nusa Tenggara untuk Meningkatkan Keterampilan Berpikir Siswa SMA. Seminar Nasional Pendidikan Sains, 223-230. 
T.N. Anggraeni et al/Indonesian Journal of Curriculum and Educational Technology Studies 7(2) (2019): $80-88$

Arry, D., Jacobs, L. C., \& Sorensen, C. (2010). Introduction to research in education (8th ed.). Belmont: Wadsworth Cengage Learning.

Badan Standar Nasional Pendidikan (BSNP). (2010). Paradigma pendidikan nasional abad XXI. Jakarta: BSNP.

Behera, S.K. (2013). M-learning: a new learning paradigm. International Journal on New Trends in Education and Their Implications, 4(2), 24-34.

Bellanca, J. A., Fogarty, R. J., \& Pete, B. M. (2012). How to teach thinking skills within the common core. Solution Tree Press: United States of America

Cabanban, C. L. G., \& Marcos, D.M. (2013). Development of mobile learning using Android platform. International Journal of Information Technology \& Computer Science, 9(1), 98-106.

Calimag, J. N., Miguel, P. A., Conde, R. S., \& Aquino, L. B. (2014). Ubiquitous learning environment using Android mobile application. International Journal of Research in Engineering $\mathcal{E}$ Technology, 2(2), 119-128.

Chin, C. (1997). Promoting higher cognitive learning in science through a problem-solving approach. National Institute of Education (Singapore), 1, 7-11.

Daniel, W.W. (1989). Statistika non parametrik terapan (Terjemahan Alex Tri Kantjono W.). New York: Hounghyon Mifflin Company.

Ditjen PMPTK. (2008). Kompetensi penelitian dan pengembangan $05-A 2$, Penulisan Modul. Jakarta: Ditjen PMPTK.

Januszewski, A., \& Molenda, M. (Eds.). (2008). Educational Technology: A Definition with Commentary. New York: Taylor \& Francis Group.

Kawamura, M., \& Wu, P. N. (2015). Developing critical thinking skills through content base learning using media. Paper presented at International Conference on Communication, Health, Beauty and Innovation Education, Jepang.
Lubis, I. R., \& Ikhsan, J. (2015). Pengembangan media pembelajaran kimia berbasis Android untuk meningkatkan motivasi belajar dan prestasi kognitif peserta didik SMA. Jurnal Inovasi Pendidikan IPA, 1(2). 191-201.

Peterson, E. (2019). Ecopedagogy: Learning How to Participate in Ecological Consciousness. CONSCIOUSNESS: Ideas and Research for the Twenty-First Century, 7(1), 1-27.

Pizzini, E. L. (1991). SSCS problem solving: implementation handbook. Iowa City: Science Education Departemen, the University of Iowa.

Pizzini, E. L., Abell, S. K., \& Shepardson, D. S. (1988). Rethinking thinking in the classroom. The Science Teacher, 55(9), 22-25.

Prastowo, A. (2014). Pengembangan bahan ajar tematik tinjauan teoritis dan praktik. Jakarta: Kencana Prenadamedia Group.

Ricci, M. C. (2013). Mindsets in the classroom. Prufrock Press Inc. United States of America

Richey, R. C. \& Klein, J. D. (2007). Design and development research: Methods, strategies and issues. Mahwah, NJ: Lawrence Erlbaum Associates, Publishers.

Subali, B. (2012). Prinsip Assessmen dan Evaluasi Pembelajaran. Yogyakarta: UNY.

Tong, J. (2016). Design and implementation of music teaching platform in college based on Android mobile technoloy. International Journal of Engineering Technologies in Learning, 11 (5), 4-9.

Yap, B. W., \& Sim, C. H. (2011). Comparisons of various types of normality tests. Journal of Statistical Computation and Simulation, 81(12). 2141-2155.

Zheng, Z., Cheng, J., \& Peng, J. (2015). Design and implementation of teaching system for mobile cross-platform. International Journal of Multimedia and Ubiquitous Engineering, 10(2). 287-296. 